\title{
A Comparison of Two Horsechestnut Street Tree Plantings in Kiev and Pripyat, Ukraine
}

\author{
A. James Downer*, John Karlik \\ Division of Agriculture and Natural Resources, University of California, Davis, CA, USA \\ Email: *ajdowner@ucanr.edu
}

How to cite this paper: Downer, A. J., \& Karlik, J. (2019). A Comparison of Two Horsechestnut Street Tree Plantings in Kiev and Pripyat, Ukraine. Open Journal of Forestry, 9, 255-263.

https://doi.org/10.4236/ojf.2019.93014

Received: June 13, 2019

Accepted: July 28, 2019

Published: July 31, 2019

Copyright ( 2019 by author(s) and Scientific Research Publishing Inc. This work is licensed under the Creative Commons Attribution International License (CC BY 4.0). http://creativecommons.org/licenses/by/4.0/

\begin{abstract}
Branch and main stem defects of horsechestnut trees (Aesculus hippocastanum L.) in Pripyat, Ukraine, abandoned in 1986, and un-maintained since then, were compared to managed trees of the same species and similar age in the city of Kiev, Ukraine. Trees in Kiev sustained more trunk injuries, and numerous pruning wounds, and developed significantly more branch defects (especially codominant stems) in their canopies compared to trees in Pripyat. Although Kiev trees had larger stem diameters, the overall quality of their form was reduced compared to street trees in Pripyat. Pripyat horsechestnuts grew with competition from other, invading trees thus, experienced shading of their lower canopies and significant competition for light and had smaller bole diameters. Effects of the Chernobyl nuclear disaster on trees in the Nuclear Exclusion Zone are also discussed.
\end{abstract}

\section{Keywords}

Aesculus hippocastanum, Branch Defects, Chernobyl, Pripyat, Horsechestnut, Codominant Stems

\section{Introduction}

On April 27, 1986, in Soviet Ukraine, reactor number four of the Chernobyl nuclear power plant exploded during a test procedure releasing over 85 petabecquerels of radiocesium $\left({ }^{137} \mathrm{Cs}\right)$, with its relatively long half-life of 30.3 years, and much more of other radionuclides into the atmosphere (Stohl et al., 2010). The accident at Chernobyl resulted in release of more radionuclides to the environment than any other nuclear accident in history, surpassing the recent disaster at Fukushima, Japan by a factor of 10 (Steinhauser et al., 2013).

After explosion of reactor four, all inhabitants of Pripyat (a nearby modern city of 50,000) were evacuated within three days. An exclusion zone (the Zone) of $30 \mathrm{~km}$ was established and over 200 villages were depopulated. Military check- 
points at 30 and $10 \mathrm{~km}$ from the reactor complex were placed to regulate movement within the Zone. Human activity in the Zone was limited following the disaster and residents were never allowed to repopulate their city and villages. Ten years after the accident, biologists noted that the $30 \mathrm{~km}$ Zone was a haven for wildlife, and vegetation was in a lush state of recovery (Freemantle, 1996). Twenty to Twenty-five years post disaster, the park-like setting within the Zone was home for seldom-seen animals, and the forests had begun extensive recovery (Moller \& Mousseau, 2006; Burlakova \& Nydich, 2012).

Radionuclides deposition after the accident was highly variable (Nesterenko, \& Yablokov, 2009). In areas where fallout was greater, such as near the power plant, and along the "Western Radiation Trace" (a linear strip of concentrated fallout), enough radiation was released to kill trees (20 - 100 sieverts), which led to the development of the iconic "Red Forest" where Scots pines (Pinus sylvestris L.) died rapidly, and turned red as they dried out. In other nearby areas such as Pripyat, fallout did not reach sufficient concentration to kill vegetation. Most street trees planted in Pripyat survived the disaster, and when the city was evacuated, were left unmaintained until present. While several studies document effects of radiation on genetic variability and mutations of animals, few show effects on trees, with Scots pine being the most studied tree species (Moller \& Mousseau, 2006). Radiation effects on horsechestnut are largely unknown.

Lacan and others (2015) examined survival and succession within Pripyat's street tree population 27 years after the reactor accident. Their overall conclusion was that trees in the zone were healthy, and recolonizing the abandoned city in areas that were once turfgrass or other areas of landscape between buildings. Many of Pripyat's original street tree plantings still remain intact after almost 30 years of human abandonment. Pripyat Landscapes are an excellent example of old-field succession where ornamental trees and landscapes are impacted by spread of urban and native tree species throughout the abandoned city (Lacan et al., 2015).

Pripyat is now mostly wooded with few open areas that have not been covered by trees (Figure 1). The most abundant successors in Pripyat's landscaped areas are Populus and Robinia (Lacan et al., 2015).

Abandonment of Pripyat after the Chernobyl nuclear accident offers an opportunity to examine the development of street trees in absence of typical maintenance practices and people pressures, usually associated with urban trees. In this study, we compare two populations of horsechestnut, one in Pripyat and one in the nearby city of Kiev (Ukrainian: Kyiv), in an attempt to assess the effects of presence or extended absence of arboricultural practice and human impact on tree structural defects and overall structural quality of the canopy.

\section{Materials and Methods}

To compare two populations of trees, we chose horsechestnut for study because it is a commonly planted tree in Kiev, where, along with Poplar (Populus spp)., 


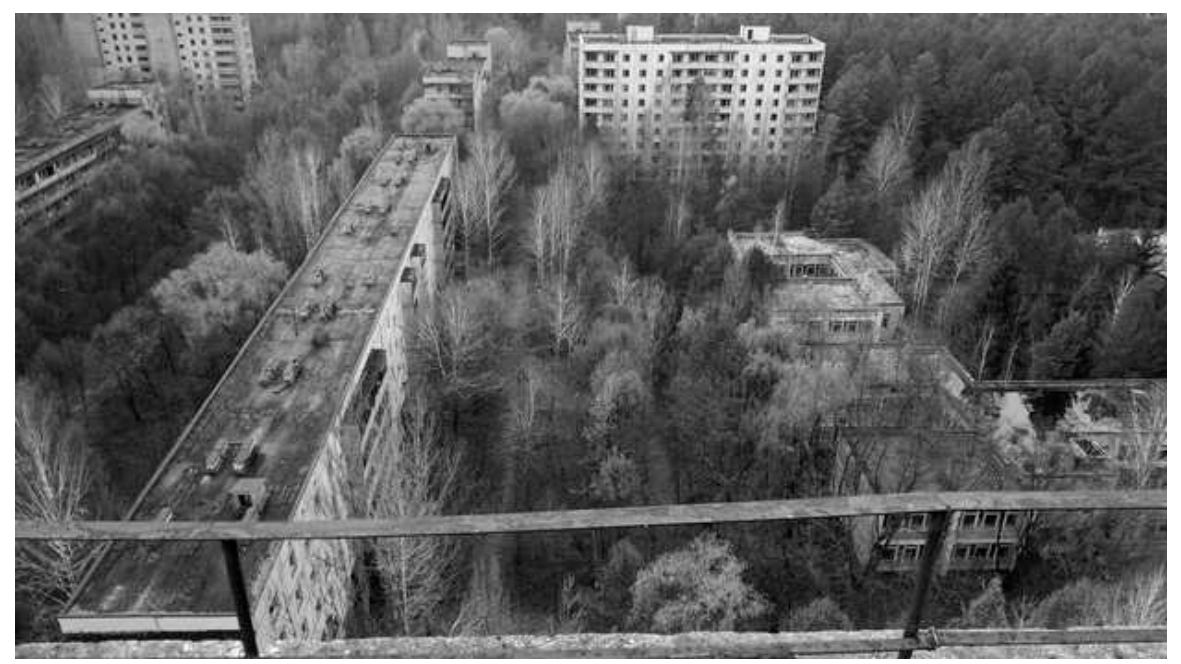

Figure 1. An image of the abandoned town of Pripyat in 2015. The city has been invaded by native and exotic tree species. The remnants of street trees can be seen on the far left. Image date $11 / 17 / 2015$.

horsechestnut lines many of the main streets in Ukraine and other East European nations. In Kiev, we selected a group along Taras Schevchenko Blvd. immediately west of Peremohy Square (50.447212 deg. longitude, 30.490545 deg. latitude). Horsechestnuts were planted in a $10 \mathrm{~m}$ wide linear center median $1 \mathrm{~m}$ from the roadway. In Pripyat we chose Lenin Blvd. (51.405142 longitude by 30.058469 latitude), an important entrance to the city, with poplars planted in the center of the street and horsechestnuts along both sides.

Efforts were made to select tree populations of similar age. Tree age at Pripyat was estimated from pictures found in a monograph about the development of the city (Anonymous, 1976) and known times of establishment of the city. In Kiev, three trees in the study population had been removed and we were able to estimate age by counting annual growth increments on the resident stumps. In a return visit to the zone in 2016, individuals from each population were cored with an increment borer to ascertain population age ( 41 and 43 years $+/-5$ years for Pripyat and Kiev respectively).

Twenty-five trees in each site were selected, measured and examined for defects. Trees were examined successively down the street row until twenty-five trees had been assessed. Trunk diameter $(\mathrm{cm})$ was measured at four feet. Each tree was examined for trunk and branch defects. Cavities and other trunk wounds were tabulated and the opening measured (length $\times$ width in $\mathrm{cm}$ ). The crude area of the trunk exposed was calculated by multiplying the length and width of each cavity. Cavity areas for all trees in each site were summed. Branch defects (codominant stems, branches all from one point, and branches headed back) were tabulated for each tree and the number of large pruning wounds along the main stem (greater than $10 \mathrm{~cm}$ ) counted. An architectural quality rating (AQR) (technique of Bond, 2012) was given by the same evaluator to each tree, which included a visual assessment of live crown ratio, overall vitality, ab- 
sences of obvious structural defects and development of appropriate form for the species. These numerical ratings ranged from 1 (tree with extensive branch faults, change in natural form or extensively damaged by pruning such that tree health is reduced) to 5 (tree with perfect form, branch architecture and health). Ratings were conducted in November, 2015 when canopies were without leaves. Further site measurements (mulch depth) and radiological measurements were taken in 2016 and 2018. Gamma radiation emissions at the soil level $50 \mathrm{~cm}$ distant from each tree were taken with a Mirion RDS-80a dosimeter. The instrument was allowed to equilibrate at each tree for $30 \mathrm{~s}$ and then a reading was taken $1 \mathrm{~m}$ above the soil surface. Caliper measurements of the main stem were made in a subsequent visit to the Zone and Kiev sites in 2018.

Numerical data were analyzed with Mintab 17 statistical software using paired and non-paired two-sample t-tests. Categorical information was further summarized in a table.

\section{Results}

\subsection{Site Observations}

Pripyat town is extensively colonized by invading tree species that have invaded all open unpaved spaces between buildings (Figure 1). Pripyat horsechestnut study trees were located within $1 \mathrm{~m}$ of remnants of the main road (Lenin Blvd.), which was in places bare or covered in leaf litter (Figure 3). Litter (mulch) buildup under Kiev horsechestnuts was negligible as trees were maintained with a clean canopy floor (Figure 2) while the Pripyat horsechestnuts sustained an extensive and thick litter layer (Figure 3). When walked upon, the litter layer was spongy or fluffy underfoot. In Kiev, all leaves and plant debris were removed from the site. There were no adjacent plantings of woody or any other plants, nor any irrigation (Figure 2). In Pripyat, there was abundant competition from seedling trees and vines (unknown spp) that had invaded the street tree planting. Poplar (Populus sp.), boxelder (Acer negundo) and locust (Robinia pseudoacacia) were numerous (all identified by bud morphology) and within the dripline of several horsechestnuts examined.

\subsection{Tree Measurements and Observations}

Analysis of stumps in Kiev gave an approximate age of the trees of 48 years. Since construction of the Pripyat began in 1970, and Lenin Blvd. was likely one of the first streets planted, we estimate the age of both populations to be within five years of each other. According to Lacan et al. (2015), there are no planning documents for Pripyat town to indicate planting dates, thus we inferred from pictures in the Pripyat monograph of 1976 (Anonymous, 1976) the inauguration date of the city (1970) and visual aerial footage from the film Raspad, (1989) showing a mature planting of cottonwood and horsechestnuts on Lenin Blvd, that the Pripyat horsechestnuts are of similar age to trees selected in Kiev for comparison. Finally counting of annular increments placed the populations within + /- five seasons of each other in age (41 - 43 years). 


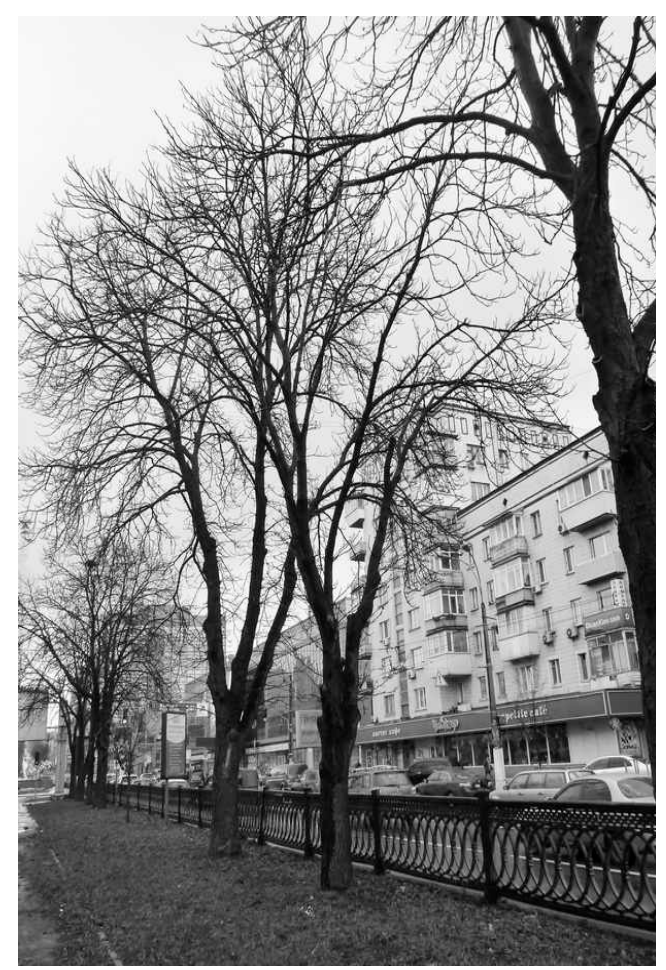

Figure 2. An image of the Kiev tree population. Note numerous branches have been removed and the natural architecture of the trees changed and codominant stems. Image taken 11/16/2015.

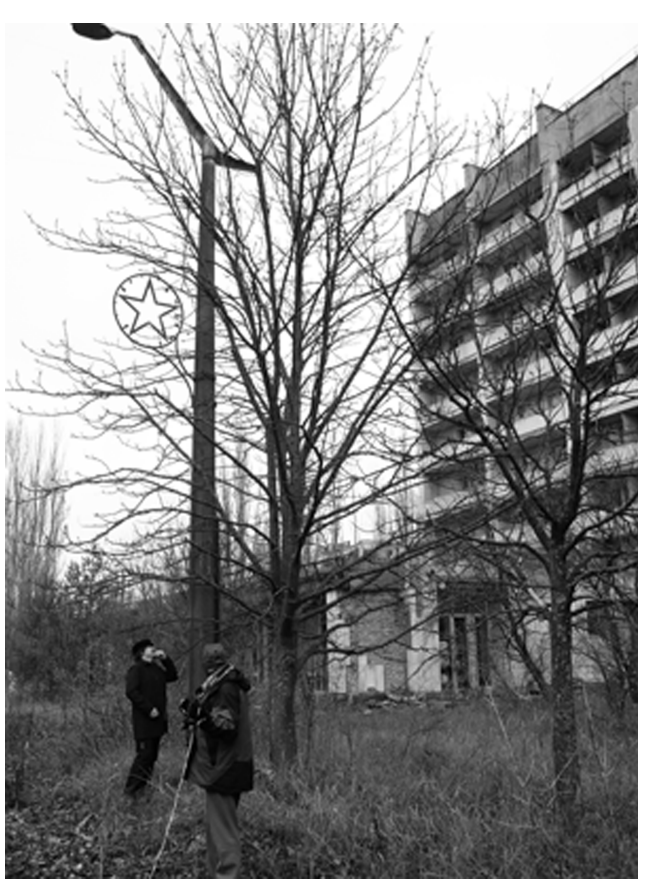

Figure 3. Sample from the Pripyat population of horsechestnuts. Note (left tree) the natural form, lack of pruning wounds and branch faults. Image taken $11 / 17 / 2015$. 
Trees in Pripyat had stem sizes (bole) on average 66\% as large as those in Kiev (Table 1). Architectural quality of Pripyat trees was significantly increased compared to those in Kiev ( $P=0.04$; Table 1$)$ Branch defects were more numerous in Kiev trees (2.5× more defects), and Kiev sustained more pruning pruning wounds (mostly limb removal along the main stem) (Table 2) with 173 large cuts on Kiev horsechestnuts compared to none in Pripyat. Main stems (boles) suffered over four times as much injured surface area on their trunks in Kiev as in Pripyat trees (Table 2). Stem and branch Defects such as heading cuts, all branches originating from a single point, and codominant stems were observed in greater frequency in Kiev than in Pripyat (Table 2; Figure 2).

The growth rate of Kiev trees was slow but significant over time. From 2015 to 2018 trees increased their diameter (measured at four feet above the soil line) by an average of $1.4 \mathrm{~cm}$ (Table 3) Trees in Pripyat did not increase in diameter over the three year measurement period.

Measurement of gamma radiation showed levels $12 \times$ greater in Pripyat than in Kiev. A little over thirty years after the release of raidionuclides from the reactor (one half life for the principle contaminant ${ }^{137} \mathrm{Cs}$ ).

\section{Discussion and Conclusion}

Tree architectural quality differences between locations were due mostly to lack of structural defects in the Pripyat trees, which had uniformly well-developed central leaders and well-attached side branches. Trees in Kiev were significantly more pruned, and had more trunk injuries than those in Pripyat, resulting in lower quality canopies. Pripyat trees had higher AQR's than those in Kiev but only slightly. That the Pripyat trees did not score higher in architectural quality was somewhat unexpected, but competition with encroaching woody vines and other trees, causing Pripyat trees to grow away from those influences, increased deadwood, and asymmetry in their canopies.

Pripyat trees had clear central leaders which gave the trees a strong excurrent shape, unlike Kiev trees which were slightly more spreading or vase-shaped (Figure 2 and Figure 3 respectively). This difference in overall appearance was

Table 1. Tree size, quality and branch defect differences between trees in Kiev and Pripyat.

\begin{tabular}{cccc}
\hline Tree Population & $\begin{array}{c}\text { Architectural Quality Rating } \\
(\mathrm{AQR})^{1}\end{array}$ & $\begin{array}{c}\text { Total Branch } \\
\text { Defects }^{2}\end{array}$ & $\begin{array}{c}\text { Codominant } \\
\text { Stems }^{3}\end{array}$ \\
\hline Kiev & $3.2 \mathrm{a}$ & $1.68 \mathrm{a}$ & $1.208 \mathrm{a}$ \\
Pripyat & $3.7 \mathrm{~b}$ & $0.68 \mathrm{~b}$ & $0.560 \mathrm{~b}$ \\
$\mathrm{t}$-value; $P$-Value & $2.12 ; 0.04$ & $3.37 ; 0.002$ & $-3.13 ; 0.003$ \\
\hline
\end{tabular}

${ }^{1}$ Architectural/Quality Rating is a rating of the health and form of the tree and where 1 is dead and 5 is a perfectly formed and healthy tree with no defects. ${ }^{2}$ Branch defects are the mean number of defects observed on each tree and include: codominant stems or all branches arising from a single point. ${ }^{3}$ Codominant stems is the mean number of codominant stem attachments observed in each tree. ${ }^{4} \mathrm{t}$ value is calculated by a two sample (not paired) $t$ Test with stated probability value for a significant population difference. Different letters signify significant differences within a column. 
Table 2. Frequencies ${ }^{1}$ of tree defects in horsechestnuts in Kiev and Pripyat.

\begin{tabular}{ccccccc}
\hline $\begin{array}{c}\text { Tree } \\
\text { Population }\end{array}$ & $\begin{array}{c}\text { Large }^{2} \\
\text { branch } \\
\text { removals }\end{array}$ & $\begin{array}{c}\text { All branches } \\
\text { from a } \\
\text { single point }\end{array}$ & $\begin{array}{c}\text { Heading } \\
\text { Cuts }\end{array}$ & $\begin{array}{c}\text { Codominant } \\
\text { stems }\end{array}$ & $\begin{array}{c}\text { Trunk } \\
\text { injuries }\end{array}$ & $\begin{array}{c}\text { Injury/cavity } \\
\text { area }^{2}(\mathrm{cc})^{3}\end{array}$ \\
\hline Kiev & 173 & 4 & 6 & 27 & 12 & 9754 \\
Pripyat & 0 & 0 & 0 & 15 & 6 & 2370 \\
\hline
\end{tabular}

${ }^{1}$ Numbers are total observed instances of the indicated defect in each population of 25 trees. ${ }^{2}$ Large branches removals are wounds greater than $7.5 \mathrm{~cm}$ diameter left on main stem from limb removal pruning. ${ }^{3}$ Numbers are an estimate of the area of the injury (length $\times$ width in $\mathrm{cm}$ ) summed for all the trees in each sample. ${ }^{4}$ Numbers are the sum of exposed trunk surface (cavity area) from all the trees in each site, cavity area is the length $(\mathrm{cm}) \times$ width $(\mathrm{cm})$ of each opening.

Table 3. Main stem growth of trees in Kiev and Pripyat.

\begin{tabular}{cccc}
\hline Tree population & \multicolumn{2}{c}{ Stem diameter $(\mathrm{cm})$} & $\mathrm{t}$ and $P$ values \\
\hline & 2015 & 2018 & \\
\hline Kiev & $54.17 \mathrm{a}$ & $55.59 \mathrm{~b}$ & $7.02,0.000$ \\
Pripyat & $28.84 \mathrm{a}$ & $28.96 \mathrm{a}$ & $-0.11,0.909$ \\
\hline
\end{tabular}

Differences between years are different if followed by a different letter in each row according to paired $t$ test $(\mathrm{n}=25)$.

likely due to an absence of main branch/stem defects induced by pruning (i.e. a lack of heading cuts) and enhanced by competition from seedling trees. The defect "all branches from the same point", so pronounced in some of the Kiev trees, was entirely absent in Pripyat. Trees in Kiev were crown-raised by removal of many lower branches and were subjected to heading cuts at various times during their maintenance. Kiev horsechestnuts have substantially more codominant stems which also tended to lower the overall architectural quality rating of these trees. As trends in shade tree pruning evolve, our study adds to the growing understanding that reduced pruning dosages and less pruning overall favors good structure. Limited "structural pruning" will produce well-formed, aesthetic and functional tree plantings (Gillman \& Grabosky, 2009).

Given similar ages of the two study tree populations, it is not surprising that trees in Kiev had significantly larger diameters than those in Pripyat since Kiev trees have a faster growth rate (Table 3) and the growth rate in Pripyat is essentially nill. Three mechanisms could explain the reduced size of Pripyat trees. Growth differences might be explained by the direct effect of fallout radionuclides on tree development as in Scots pine (Mousseau et al., 2013) where trees that were exposed to the most radiation grew the least. We measured a $12 \times$ increased gamma radiation at the trees in Pripyat over 30 years after the accident (Table 4). Earlier in their lives, the Prypiat trees were certainly absorbing much more gamma radiation perhaps to damaging levels. A striking difference in the two sites is the presence of thick litter layers under all the trees in Pripyat which should have supported a healthy growth response. Mousseau et al., (2014) suggest that reduced mass loss from litter is the result of radiation effects on soil mycoflora. In the most contaminated sites near the Chernobyl reactor, litter 
Table 4. Radiation levels in Kiev and Pripyat tree study sites.

\begin{tabular}{cc}
\hline Tree Population & Gamma Radiation (CPM) \\
\hline Kiev & $44.6 \mathrm{~b}$ \\
Pripyat & $550.8 \mathrm{a}$ \\
\hline
\end{tabular}

Radiation measured at each tree with a Mirion RDS-80a in 2018. Measurements significantly different according to two sample $\mathrm{t}$ test; $\mathrm{t}$ value $31.5, P=0.000$, different letters indicate a significant difference according to the above tests.

decomposition was reduced by $40 \%$ compared to loss in areas of normal background radiation in Ukraine. Retardation of litter decomposition results in less nutrient cycling for trees growing in contaminated forests and in less growth. Also trees in Pripyat would not have experienced the anthropogenic deposition of minerals that trees in cities endure. Even though there was no litter/mulch accumulation under Kiev trees, urban centers are rich sources of anthropogenic nutrients that can act as fertilizers (Egerton-Warburton \& Allen, 2000) thus supplying mineral nutrients in absence of forest litter. Pripyat trees, deprived of mineralized nutrients from organic matter could have been retarded in their growth. The third explanation for tree size differences is that the presence of seedling trees, vines and shrubs growing in near proximity and in competition with the Pripyat horsechestnuts which competed for water and nutrients and thus slowed horsechestnut growth over time. We observed considerable die-back of lower small branches in the Pripyat trees attributable to shading from the numerous stems of invading trees in close proximity.

Our assessment of Kiev trees confirms that arboriculture as a profession is relatively new in Ukraine and proper pruning practices are only recently being introduced by local arborists. Their practices and efforts to educate public agencies about appropriate tree management will undoubtedly result in gradual improvement in condition of Kiev trees.

\section{Acknowledgements}

The authors thank and acknowledge Sergii Mirnyi of Chernobyl tours for his guidance in the Zone; Valentine Skubak and Igor Singer (Kiev Arborists) for their assistance in age estimates of the Kiev horsechestnuts and Igor Lacan for manuscript review.

\section{Conflicts of Interest}

The authors declare no conflicts of interest regarding the publication of this paper.

\section{References}

Anonymous (1976). Pripyat: A Photo-Story about a New City of Pripyat, in the Kiev District of the People's Socialist Republic of Ukraine. Kiev: Mistetstvo. (In Ukrainian and Russian)

Bond, J. (2012). Urban Tree Health: A Practical and Precise Estimation Method. Geneva: 
Urban Forest Analytics Llc.

Burlakova, E. B., \& Naydich, V. I. (2012). The Lessons of Chernobyl: 25 Years Later. Hauppauge, NJ: Nova Science Publishers.

Egerton-Warburton, L. M., \& Allen, E. B. (2000). Shifts in Arbuscular Mycorrhizal Communities along an Anthropogenic Nitrogen Deposition Gradient. Ecological Applications, 10, 484-496. https://doi.org/10.1890/1051-0761(2000)010[0484:SIAMCA]2.0.CO;2

Freemantle, M. (1996). Ten Years after Chernobyl Consequences Are Still Emerging. Chemical \& Engineering News, 74, 18-28. https://doi.org/10.1021/cen-v074n018.p018

Gillman, E. F., \& Grabosky, J. (2009). Growth Partioning Three Years Following Structural Pruning of Quercus virginiana. Arboriculture \& Urban Forestry, 35, 281-286.

Lacan, I., McBride, J. R., \& De Witt, D. (2015). Urban Forest Condition and Succession in the Abandoned City of Pripyat, near Chernobyl, Ukraine. Urban Forestry \& Urban Greening, 14, 1068-1078. https://doi.org/10.1016/j.ufug.2015.09.009

Moller, A. P., \& Mousseau, T. A. (2006). Biological Consequences of Chernobyl: 20 Years on. Trends in Ecology \& Evolution, 21, 200-207.

https://doi.org/10.1016/j.tree.2006.01.008

Mousseau, T. A., Milinevsky, G., Kenney-Hunt, J., \& Moller, A. P. (2014). Highly Reduced Mass Loss Rates and Increased Litter Layer in Radioactively Contaminated Areas. Oecologia, 175, 429-437. https://doi.org/10.1007/s00442-014-2908-8

Mousseau, T. A., Welch, S. M., Chizhevsky, I., Bondarenko, O., Milinevsky, G., Tedeschi, D. J., Bonisoli-Alquati, A., \& Moller, A. P. (2013). Tree Rings Reveal Extent of Exposure to Ionizing Radiation in Scots Pine Pinus sylvestris. Trees, 27, 1443-1453. https://doi.org/10.1007/s00468-013-0891-Z

Nesterenko, V. B., \& Yablokov, A. V. (2009). Chernobyl Contamination an Overview. In J. D. Sherman-Nevinger (Ed.), Chernobyl Consequences of the Catastrophe for People and the Environment Vol. 1181 (Annals of the New York Academy of Sciences) (pp. 4-30). Hoboken, NJ: Wiley-Blackwell. https://doi.org/10.1111/j.1749-6632.2009.04820.x

Steinhauser, G., Brandt, A., \& Johnson, T. E. (2013). Comparison of the Chernobyl and Fukushima Nuclear Accidents: A Review of Environmental Impacts. Science of the Total Environment, 470-471, 800-871. https://doi.org/10.1016/j.scitotenv.2013.10.029

Stohl, A., Seibert, P., Wotawa, G., Arnold, D., Burkhart, J. F., Eckhardt, S., Tapia, C., Vargas, A., \& Yasunari, T. J. (2010). Xenon-133 and Caesium-137 Releases into the Atmosphere from the Fukushima Dai-ichi Nuclear Power Plant: Determination of the Source Term, Atmospheric Dispersion and Deposition. Atmospheric Chemistry and Physics, 12, 2313-2343. https://doi.org/10.5194/acp-12-2313-2012 